\title{
Leigos e leigas: história e interpretação
}

\section{Laymen and laywomen: history and interpretation}

Antonio José de Almeida

\section{Resumo}

"Leigo" é um termo que cobre uma ampla gama de significados. O fenômeno está ligado às distintas situações eclesiais, canônicas e teológicas vividas pelos leigos ao longo da história do cristianismo. Percorrer a história dessas variações semânticas e interpretações teológicas é o objeto deste trabalho, com o intuito de oferecer aos que refletem sobre o tema do "laicato" um instrumento capaz de revelar aspectos novos ou desconhecidos da questão. A reflexão parte do Novo Testamento, onde significativamente não aparece o termo "leigo" e chega aos dias atuais, em que tendências bastante diferentes entre si disputam a interpretação mais adequada destes sujeitos eclesiais, os leigos e as leigas, que, em que pesem as contradições os vaivéns, têm conquistado sempre maior espaço e reconhecimento na vida e missão da Igreja.

Palavras-chave: Leigo; Hierarquia; Igreja; Missão.

\begin{abstract}
"Lay" is a term that covers a wide range of meanings. The phenomenon is linked to the different ecclesial, theological and canonical situations experienced by lay people throughout the history of Christianity. Go through the history of these semantic variations and theological interpretations is the
\end{abstract}


object of this work, in order to provide reflecting on the theme of "laity" an instrument capable of revealing new aspects or unknown of the question. Reflection of the New Testament, which significantly not appear the term "lay" and reaches the present day, where quite different trends each other vying for the most appropriate interpretation of these ecclesial subjects, lay men and women who, in spite of the contradictions and shuttles have gained ever greater space and recognition in the Church's life and mission.

Keywords: Lay; Hierarchy; Church; Mission.

\section{Introdução}

O termo "leigo" tem sido usado nos mais diversos sentidos. Quem o usa, porém, geralmente o faz como se o significado que ele lhe atribui fosse único e universal. Observa-se esse fato tanto nas falas corriqueiras como em contextos mais específicos, como o eclesial, ou ainda mais restritos, como o meio acadêmico. O desafio é este: o que se diz quando se diz "leigo"? A resposta é clara: dizem-se tantas e tão diferentes coisas... que o desafio continua. E, para descrevê-lo, se usam termos e expressões ao desalcance da maioria: "polissemia", "polivalência semântica", "pluralidade de significados".

Como em tantas questões, o caminho da história parece o mais indicado para se obter e lançar alguma luz neste emaranhado semântico. As palavras, aliás, não têm um sentido em si, absoluto e imutável. O significado de uma palavra é seu uso na sentença. ${ }^{1}$ Além disso, seu sentido é sempre socialmente e historicamente situado. Daí a necessidade de conhecer os contextos históricos e sociais em que atores diversos, em posições, sob inúmeros aspectos, diferentes, se relacionam e se relacionam com a realidade, para poder captar as compreensões que têm de si, dos outros e das coisas que exprimem na linguagem.

No caso dos leigos e leigas (essas demoraram séculos para receber este nome!), parece de bom alvitre começar pelo sentido etimológico, onde, aliás, os autores já se dividem, pois, enquanto uns querem que o termo "leigo" (em grego, "laikós") tenha a ver meramente com "laós" - significando, então, membro do povo - outros fazem questão de mostrar que "laikós" tem um sentido especificante: aquela parte do povo que não pertence à administração do povo. O dicionário não justifica, mas explica: “Adj. 1. Que não é clérigo;

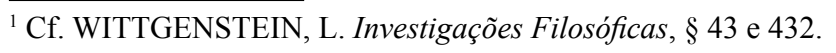


laical, laico. (...) 2. Que pertence ao povo cristão como tal e não à hierarquia eclesiástica. (...) 3. Fig. Que é estranho ou alheio a um assunto; desconhecedor. (...) S. m. 4. Indivíduo leigo.”2 Uma das intenções deste trabalho é justificar.

Feita esta rápida incursão etimológica, o foco se voltará mais para o leigo "ator social" do que para leigo "palavra", também social, é claro. O contexto primeiro será a Igreja (o útero em que o leigo foi concebido, nasceu da Igreja Virgem, padeceu sob tantos Pilatos, foi morto e sepultado, para, nos penúltimos tempos, ressuscitar), depois, o mundo (com o qual a Igreja tem vivido relações de amor, ódio, arrependimento e ressentimento). A um Voltaire - por exemplo - que conclamava os franceses a "écraser l'infame" (esmagar o infame) $)^{3}$, o cristianismo, Pio IX, um século depois, respondia anatemizando quem dissesse que "o Romano Pontífice pode e deve reconciliar-se e transigir com o progresso, com o liberalismo e com a moderna civilização"4, para ser desmentido por Paulo VI, que, no discurso de encerramento do Vaticano II, afirmou que "uma corrente de afeto e de admiração se despejou do Concílio sobre o mundo humano moderno." ${ }^{5} \mathrm{Na}$ verdade, entre Igreja e mundo há uma relação sociologicamente ineliminável: o mundo, em toda a sua complexidade, com suas muitas auto-compreensões e percepções, é o contexto maior em que a Igreja, com sua organização, práxis e reflexão dialeticamente interrelacionadas, vive e atua. ${ }^{6}$

Não se pretende elaborar cuidadosos "modelos" interpretativos", mas trazer à luz as falas presumidamente mais significativas sobre os leigos ao longo da história da Igreja. Desde sua primeira aparição na literatura cristã até às mais recentes. Nas elucubrações dos teólogos e nos pronunciamentos do Magistério. Nas precisões dos canonistas e nos boquejamentos de não poucos ouvidos moucos. Enfim, o foco é a fala, mais que o falante. Se bem que relacionar fala e falante seria exercício ainda mais fecundo.

\footnotetext{
${ }^{2}$ AURELIO BUARQUE DE HOLANDA FERREIRA. Novo dicionário da língua portuguesa. Rio de Janeiro: Nova Fronteira, 1975, p. 833.

${ }^{3}$ Cf. POMEAU, R. La religion de Voltaire. Paris: Nizet, 1969², pp. 309-310.

${ }^{4}$ PIO IX. Quanta cura (Syllabus complectens praecipuos nostrae aetatis errores, proposição LXXX).

${ }^{5}$ PAULO VI. "Alocução na última sessão pública do Concílio ecumênico Vaticano II", 7 de dezembro de 1965. Disponível em: <vatican.va>.

${ }^{6}$ Cf. ZIRKER, H. Ecclesiologia. Brescia: Queriniana, 1987, pp. 30-36.

${ }^{7}$ Cf. CANOBBIO, G. "La riflessione teológica sui laici dal Concilio a oggi”. In: NAVARRO, L. - PUIG, F. Il fedele laico. Realtà e prospettive. Milano: Giuffrè, 2012, pp. 11-34.
} 
A literatura em língua portuguesa é escassa nessa matéria; daí o recurso à literatura europeia, sobretudo italiana, até por uma deformação da formação inicial e continuada. Este diálogo, porém, pode ser útil. Se é verdade que a reflexão sobre o leigo brotou e se alimentou das práticas concretas, também é verdade que, sobretudo nos últimos duzentos anos, a Igreja europeia foi pioneira nesta matéria e tem um cabedal imenso de experiências e reflexões preciosas a oferecer à Igreja toda. Que se pense em Mounier, Maritain, Congar, Thils, Philips, quanto à elaboração teórica; num Ozanam, num Cardijn, num Schumann, num Dag Hammarskjöld, num Lazzati, pela prática social e também teórica.

A esperança é que as reflexões a seguir possam contribuir para o avanço, o aprofundamento e o discernimento da caminhada dos leigos e das leigas do Brasil, particularmente neste "Ano do Laicato", 50 aniversário do encerramento do Concílio Vaticano II (7 de dezembro de 1965), que, entre tantos epítetos, recebeu o de "concílio dos leigos".

\section{Nem clero nem leigos}

O termo "laikós" não se encontra no Novo Testamento ${ }^{8}$. Mais do que documentar a presença de categorias distintas - e opostas - no interior do povo de Deus, o Novo Testamento nos põe em contato com uma comunidade, a Igreja, que se define por sua relação com Deus ou com Cristo: $\varepsilon \kappa \kappa \lambda \varepsilon \sigma i \alpha$

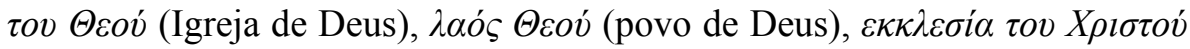

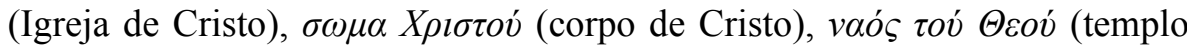
de Deus), koinonía toû hagíou pneúmatos (comunhão do Espírito Santo). A totalidade dos cristãos e cristãs, que formam o $\lambda \alpha o ́ \varsigma$ $\Theta \varepsilon o v ́$ (= povo de Deus), é um só e mesmo $\kappa \lambda \eta ́ \rho o s$, no sentido totalizante que a palavra tem no Novo Testamento ( $\kappa \lambda \dot{\rho} \rho o \varsigma=$ sorte, herança): "O Novo Testamento não conhece um laicato, mas um povo, um povo santo, um povo eleito, um povo colocado à parte, um $\kappa \lambda \eta ́ \rho o \varsigma$ que exerce em sua totalidade um sacerdócio real..." 9

\footnotetext{
${ }^{8}$ Cf. POTTERIE, I. "L'origine et le sens primitif du mot laïc". Nouvelle Revue Théologique 80 (1959), pp. 840-853; IBIDEM, La vie selon l'Esprit, Unam Sanctam, 55. Paris: Cerf, 1965, pp. 13-29; JOURJON, M. "Les premiers emplois du mot laïc dans la littérature patristique". Lumière et Vie 65 (nov.-dic. 1963), p. 37-42; LANNE, E. "Le laïcat dans l'Église ancienne". Verbum Caro. Revue théologique et ecclésiastique 71-72 (1964), pp. 105-126.

${ }^{9}$ FAIVRE, A. Les Lä̈cs aux origines de l'Église. Paris: Centurion, 1984, p. 19; cf. DUPUIS, J. "Lay People in Church and World. The Contribution of Recent Literature to a Synodal Theme". Gredorianum 68 (1-2/1987), p. 348.
} 
Os membros dessa comunidade são todos chamados $\kappa \lambda \dot{\eta} \tau o l$ (eleitos), ' $\alpha \gamma \iota$ เ (santos), $\mu \alpha \theta \eta \theta \alpha l$ (discípulos), mas, principalmente, $\alpha \delta \varepsilon \lambda \varphi o l$ (irmãos), pois formam uma $\alpha \delta \varepsilon \lambda \varphi o \tau \eta \varsigma$ (fraternidade) (cf. At 6,3 ; 1 Cor 6,6$)^{10}$.

$\mathrm{O}$ pano de fundo de todas essas expressões é a idéia daquele povo messiânico-escatológico que Deus reúne para si, para seu Reino ${ }^{11}$, para a participação na vida eterna em Cristo, superando os limites de uma nação, de uma cultura, das coordenadas de tempo e espaço. Aqueles e aquelas que, pela graça e pela fé, respondem ao chamado começam a fazer parte desse povo, entram em comunhão com Cristo e, nele, participam da vida divina (cf. 1Jo 1,1-3) e da vida/sorte dos irmãos e irmãs. O chamado e a resposta os

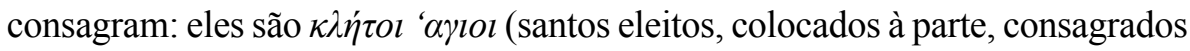
a Deus). Aqueles que não eram povo agora são o povo de Deus (cf. 1Pd 2,10) e recebem os predicados do povo do Antigo Testamento: reino sacerdotal ou sacerdócio santo (cf. Ex 19,6; Is 43,20-21; 1Pd 2,9-10), templo espiritual (cf. 1Cor 3,16ss.; 2Cor 6,16ss.; Ef 2,19-22; Hb 10,21ss.), habitação do rei celeste, onde lhe é tributado um culto espiritual, cujo princípio é o próprio Espírito Santo (cf. Ap 1,6; 1Pd 2,5; Rm 12,1).

Neste horizonte de compreensão, não se ressaltam tanto as diferenças entre "sacerdotes" e "leigos" no interior da Igreja - as duas categorias não se encontram na Igreja do Novo Testamento - mas a distinção, melhor, a antítese, entre a Igreja, totalmente consagrada a Deus, e o mundo, não no sentido

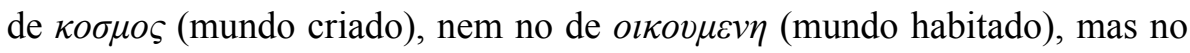
de mundo alienado pelo pecado ( ' $\alpha \mu \alpha \rho \tau \iota \alpha$ ), distanciado de Deus, mas do qual Deus se aproxima no seu Filho para reconciliá-lo consigo e para salvá-lo de suas misérias (às vezes, expresso pelo termo $\alpha l o v$ ). Com este mundo, o cristão não pode conformar-se (cf. Rm 12,2); este mundo odeia os discípulos de Cristo, que não são do mundo (cf. Jo 17,16); os discípulos não podem amá-lo (cf. 1Jo 2,15.17). Mesmo assim, Jesus pede ao Pai que não tire os discípulos do mundo (cf. Jo 17,15): apesar de pecador, continua a ser de Deus, na ordem da criação e da salvação. ${ }^{12}$ É a este mundo que os discípulos são enviados para levar a boa notícia da salvação (cf. Mt 28,19; At 1,8). O povo de Deus - eleito, chamado, colocado à parte e consagrado - tem uma missão de

\footnotetext{
${ }^{10}$ Cf. RATZINGER, J. Fraternità cristiana. Brescia: Queriniana, 2005.

${ }^{11}$ Cf. HOFFMANN, J. "La Iglesia fundada en el acontecimiento Cristo". In: LAURET, B. REFOULÉ, F. (ed.). Iniciación a la práctica de la teologia. Dogmática 2. Madrid: Cristiandad, 1985, pp. 87-137.

${ }^{12}$ Cf. CHARALAMBIDDIS, S. “Cosmología cristiana”. In: IBIDEM, pp. 19-22.
} 
testemunho ( $\mu \alpha \rho \tau \nu \rho i \alpha)$ nas suas relações com o mundo, uma missão verdadeiramente profética. Não há contradição entre "ser colocado à parte" e receber uma missão em relação ao "todo" ou a "todos". Na história da salvação, a parte está sempre em função do todo (pars pro toto, parte pelo todo)! $!^{13}$

A vigorosa afirmação da unidade do povo de Deus e de sua oposição ao mundo (terceiro sentido do termo "mundo" no Novo Testamento) não impede a afirmação de uma articulada diferenciação no interior deste mesmo povo. Existem dons espirituais $(\chi \alpha \rho i \sigma \mu \alpha \tau \alpha)$ : são aptidões da natureza e da graça dados livremente pelo Espírito a cada um em vista da utilidade ou da edificação comum (cf. 1Cor 12,7; 14,26; 1Pd 4,10). Cada um deve colocar a serviço dos outros a graça que de graça recebeu (cf. 1Pd 4,10; G1 5,13; 6,1ss.). Os carismas são dons ao mesmo tempo pessoais e comunitários e deixariam de ser carismas se perdessem uma dessas duas dimensões. Não só. Além dos carismas, existem serviços e ministérios, que são formas específicas que alguns carismas tomam em sua dimensão social e comunitária: a forma de papéis específicos, estáveis, importantes e até mesmo necessários ao ser, à

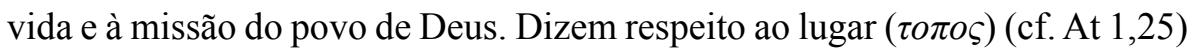
ou à parte $(\kappa \lambda \varepsilon \rho o \varsigma)(\mathrm{cf} .1 \mathrm{Pd} 5,3)$ que alguns têm na comunidade em virtude da função recebida, que, por sua própria natureza, está ligada a um carisma particular. Estas funções - com o Novo Testamento devemos chamá-las de "minis-

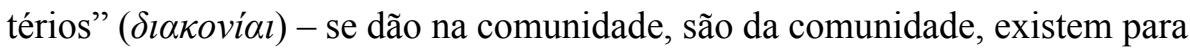

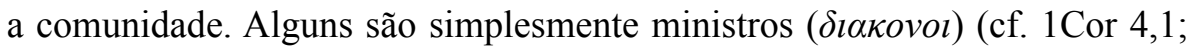
$3,6 ; 6,4)$; outros presidem ( $\pi \rho o$ or $\alpha \mu \varepsilon v o l$ ) (cf. 1Ts 5,12; Rm 12,8); há comunidades que os chamam de guias (' $\eta \gamma o v \mu \varepsilon v o r)$ (cf. Hb 13,7.17.24); em algumas áreas, sobressaem os epíscopos ( $\varepsilon \pi \imath \sigma \kappa o \pi o l)$ (cf. Fl 1,1); em outras, os presbíteros $(\pi \rho \varepsilon \sigma \beta v \tau \varepsilon \rho \rho \imath)$ (cf. Tt 1,5); às vezes, esses dois últimos títulos se equivalem (cf. At 20,17.28); conhecem-se também pastores (cf. Ef 4,11), doutores (cf. At 13,1; 1Cor 12,28). A lista iria longe e talvez não conseguisse abarcar todos os serviços e ministérios presentes nas Igrejas do Novo Testamento: "Cada cristão tem seu carisma, porque toda vida na Igreja [toute vie dans l’Église - n.d.a.] supõe uma ação do Espírito em cada um dos seus membros. A Igreja primitiva tinha um sentido agudo dessa realidade, sem conseguir, por outro lado, explicar exatamente as relações entre o carisma e a instituição." 14

${ }^{13}$ Cf. CONGAR, Y. Vaste monde, ma paroisse: vérité et dimensions du salut. Paris: Témoignage Chrétien, 1959, p. 17.

${ }^{14}$ LANNE, E. "Le laïcat dans l'Église ancienne”, Op. cit., p. 121; cf. DELORME, J. (ed.). El ministerio y los ministerios según el Nuevo Testamento, Op. cit. 
Esta perspectiva neotestamentária tem sido retomada a partir dos anos setentas, sobretudo a partir da obra Ministères et communion ecclésial, na qual Congar submete a um "exame crítico global" o contributo que procurou dar a "uma teologia do laicato e dos ministérios." ${ }^{15}$ Congar começa advertindo que "a realidade pastoral, como também o Novo Testamento, impõem uma perspectiva muito mais rica [que a da "teologia do laicato" - n.d.a.]. É Deus, é Cristo que, com o seu Espírito Santo, não cessa de construir a sua Igreja."16 A comunidade aparece como a realidade englobante, "no interior da qual os ministérios, também aqueles instituídos e sacramentais, se situariam como serviços para aquilo que é chamada a ser e a fazer." ${ }^{17}$ Mesmo correndo o risco de certo esquematismo, o grande eclesiólogo propõe dois esquemas.

A proposta de Congar parte da consideração da comunidade:

a entrada pela porta ou pelo conceito de 'comunidade' seria mais adequada. (...). Nós cremos que o Cristo quis uma comunidade estruturada. (...). Jesus instituiu uma comunidade estruturada, uma comunidade inteiramente santa, sacerdotal, profética, missionária, apostólica, com ministérios no seu interior: alguns livremente suscitados pelo Espírito, outros ligados com a imposição das mãos à instituição e à missão dos doze. (...) A Igreja é uma comunidade construída por um grande número de serviços... Não é mais o leigo que tem necessidade de uma definição, mas o sacerdote. ${ }^{18}$

A partir de então, difundiu-se a tese segundo a qual o binômio decisivo não é tanto o de "sacerdócio - laicato" (ou "hierarquia - laicato"), mas o de "comunidade - ministérios", perspectiva que foi tão importante na década de 80 que se chegou, em alguns ambientes, a decretar o fim, após cerca de 1800 anos de tranquila cidadania, de uma reflexão teológica que recorresse à categoria de leigo ou leiga. Afinal, já o Novo Testamento desconhecia uma estruturação da Igreja declinada em sacerdócio e laicato ou hierarquia e laicato. ${ }^{19}$

\footnotetext{
${ }^{15}$ CONGAR, Y. Ministeri e comunione ecclesiale. Bologna: EDB, 1973, p. 11.

${ }^{16}$ Ibidem, p. 12.

${ }^{17}$ Ibidem, p. 19.

${ }^{18}$ Ibidem, pp. 18.19. 22.

${ }^{19}$ Cf. TORRELL, J.-P. Um povo sacerdotal. São Paulo: Loyola, 2014.
} 


\section{Só há leigos quando há um clero}

O termo "leigo" aparece a primeira vez na literatura cristã na Carta de Clemente Romano aos Coríntios, escrita em torno dos anos 96-98: "Ho laikós ánthropos tois laikois prostrágmasín dédetai" (o homem leigo está submetido às prescrições leigas)." ${ }^{20}$ Trata-se, porém, de "frase enigmática que alguns consideram a origem do laicato cristão, enquanto outros sustentam que se refere a alguém que é como um judeu, que não aceita os caminhos cristãos, e que, por conseguinte, privado da verdadeira sabedoria, tem só obrigação de obedecer." ${ }^{21}$

Em outro Clemente, entretanto - o de Alexandria, que viveu entre os anos 150 e 215 - a palavra "leigo" "aparece já com um significado parecido ao moderno." 22 Segundo os estudiosos, foi, de fato, Clemente de Alexandria, em torno do ano 180, quem, com toda a certeza, empregou, pela primeira vez, em contexto linguístico indiscutivelmente cristão, o termo leigo. Argumentando contra os encratistas, que denigriam o casamento, ele apela Paulo (cf. 1Tm 5,14), escreve: "Naì mén kaì tón tês miâs guinaikós ándra pány apodéchetai kàn presbýteros e kàn diákonos kàn laïkós" (sem dúvida, ele admite o homem de uma só mulher, seja ele presbítero, seja diácono, seja leigo). ${ }^{23}$

O amanhecer do terceiro século marca uma virada para a história do povo fiel. Improvisamente vemos reutilizado o termo 'leigo', que tínhamos apenas entrevisto no primeiro século na carta de Clemente Romano. Contemporaneamente, se forma e se difunde o conceito de clero (...) Se existem na história das instituições cristãs momentos excepcionais, a passagem entre o segundo e o terceiro século certamente faz parte destes. Enquanto, para todo o século II, as informações sobre as comunidades cristãs e sobre a sua organização são raras, enigmáticas, difíceis de colocar no tempo e no espaço, o início do século III apresenta Igrejas cristãs já bem estruturadas e bem integradas no Império Romano ${ }^{24}$.

É com estas palavras que A. Faivre abre a história do laicato no século III, o século de ouro do cristianismo antigo.

${ }^{20}$ CLEMENTE ROMANO. Carta aos Coríntios 40,5: SC 167,166.

${ }^{21}$ C. O’DONNELL, C. - PIÉ-NINOT, S. Diccionario de Eclesiología. Madrid: San Pablo, 2001, p. 630.

${ }^{22}$ Ibidem.

${ }^{23}$ CLEMENTE DE ALEXANDRIA. Stromata 3, 12, 90: PG 8, 1177-1192.

${ }^{24}$ FAIVRE, A. I laici nelle origini della Chiesa. Cinisello Balsamo (MI): Paoline, 1986, pp. 61 e 93. 
As Igrejas locais são, no III século, organismos vivos auto-suficientes que se dotam dos serviços específicos indispensáveis:

A Igreja - para o cristão - é a Igreja local. Todo cristão faz parte de uma comunidade local e, conseqüentemente, é a realidade primária que se percebe em sua visibilidade concreta. Em cada cidade se forma uma única Igreja, manifestando, assim, o sentido profundo da unidade ${ }^{25}$.

Um só bispo para cada Igreja local (mono-episcopado ou episcopado monárquico); escolhido pela comunidade e intransferível; é ordenado pelos bispos das comunidades vizinhas (pelo menos três, depois de Niceia, can. 4). Ele é o símbolo da comunhão na sua Igreja local, da sua Igreja local com as demais e, portanto, da apostolicidade, ou seja, da continuidade da(s) Igreja(s) de hoje com a Igreja dos apóstolos. ${ }^{26}$

No interior de cada comunidade local, distinguem-se ordo (ministros ordenados) e plebs (povo), isto é, clérigos e leigos. Já no despontar do III século,

todos os autores (Tertuliano para a Igreja de Cartago, Hipólito para a de Roma, Clemente e Orígenes para a de Alexandria) são concordes em dar a entender que já existe uma 'fronteira' dentro do povo dos batizados. Essa fronteira leva a cindir o povo cristão em dois: os clérigos e os leigos. Dentro de cada um desses grupos, coabitam diversas funções ${ }^{27}$.

O vocabulário não podia ser mais claro. Se, com Clemente de Alexandria, aparecera, pela primeira vez, em contexto cristão e claramenete referido à estrutura da Igreja, o termo "leigo", coube a Tertuliano, nos primeiros anos do século III, dar-lhe seu sentido técnico: o leigo é um não-sacerdote. Em Tertuliano, de fato, os leigos estão assimilados à plebs (o povo, a plebe), são distintos do ordo sacerdotalis (ordem sacerdotal) ou ordo ecclesiasticus (ordem eclesiástica) $^{28}$, ou seja, dos bispos, e diáconos ${ }^{29}$ e, em geral, do clero ${ }^{30}$,

${ }_{25}$ VILLAR, J. R. Teología de la Iglesia particular. Pamplona: EUNSA, 1989, p. 382; cf. BARDY, G. La théologie de l'Église de saint Clément de Rome à saint Irénéé. Paris: Cerf, 1945, pp. 19-53.

${ }^{26}$ Cf. LEGRAND, H. "Ministerios de la Iglesia local". In: B. LAURET, B. - REFOULÉ, F. Iniciación a la práctica de la teologia, Op. cit., pp. 186-193.

${ }^{27}$ FAIVRE, A. I laici nelle origini della Chiesa, Op. cit., p. 95.

${ }^{28}$ TERTULIANO. Exortação à castidade 7.

${ }^{29}$ Idem, Sobre o batismo 17, 2; A prescrição dos heréticos 41, 8; Sobre a fuga na perseguição 11, 1.

${ }^{30}$ Idem, A monogamia 11-12. 
formado pelos chefes (duces) e pastores ${ }^{31}$. Não obstante todas as variações semânticas, este é o sentido-base que perdurará ao longo dos séculos.

Alguns documentos canônico-litúrgicos do III século não deixam lugar à dúvida. A Tradição Apostólica, de Hipólito Romano, ao mesmo tempo em que descreve o que existe na Igreja, prescreve o que deve existir. Em seu número 10, usando um vocabulário técnico, justifica a fronteira clérigo-leigo: "Quando se institui ( $\kappa \alpha \theta l \sigma \tau \alpha \sigma \theta \alpha \imath)$ uma viúva, ela não é ordenada ( $\chi \varepsilon \iota \rho o \tau o v \varepsilon \imath v)$, mas designada com (esse) título. Se seu marido morreu há muito tempo, seja instituída. Mas se seu marido morreu há pouco tempo, não se deposite nela muita confiança; mas (também) se é idosa, seja submetida a prova por certo tempo. Porque muitas vezes as paixões envelhecem com quem lhes dá espaço em si mesmo. A viúva seja instituída $(\kappa \alpha \theta l \sigma \tau \alpha \sigma \theta \alpha l)$ somente através da palavra e vá

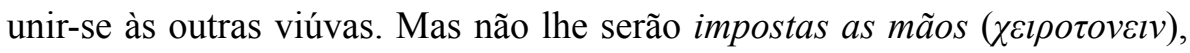
porque ela não oferece o sacrifício $(\pi \rho o ́ \sigma \varphi \rho \rho \alpha)$ e não desempenha serviço

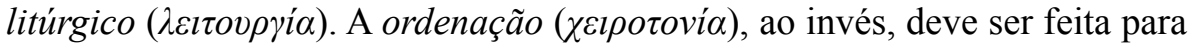
os clérigos ( $\kappa \lambda \varepsilon \rho \circ \varsigma)$ com vistas ao serviço litúrgico ( $\lambda \varepsilon ı \tau o v \rho \gamma i ́ \alpha)$. A viúva, ao contrário, é instituída ( $\kappa \alpha \theta l \sigma \tau \alpha \sigma \theta \alpha l)$ para a oração, que é (o papel comum) a todos" 32 . A normativa é clara: "ordenação" para o clero, formado por um bispo, presbíteros e diáconos (cf. Orígenes, Hipólito, Tertuliano); "instituição" para as demais categorias ou funções (viúvas, leitores, etc.). A fronteira clérigos-leigos é absolutamente clara e as duas essências, incomunicáveis!

\section{Onde há super-clérigos, os leigos são sub-cristãos}

Esse fenômeno, que se comprende facilmente a partir da necessária divisão do trabalho em toda sociedade - e a Igreja é um grupo social - sofreu muito cedo uma deriva: a identidade do clero

está dialeticamente ligada ao desapossamento religioso dos leigos (os "clérigos" insistem em que os "leigos" não sabem e não podem) e sublinham a própria eleição e superioridade. Esse mecanismo social da constituição de um clero - no sentido em que implica a desqualificação religiosa do povo cristão - ainda que pouco compatível com o Novo Testamento, penetrará com bastante rápidez em certos âmbitos da Igreja. ${ }^{33}$

\footnotetext{
${ }^{31}$ Idem, Sobre a fuga na perseguição 11.

${ }^{32}$ HIPÓLITO ROMANO. Tradição Apostólica 10.

${ }^{33}$ LEGRAND, H. "Ministerios de la Iglesia local”. In: LAURET, B. - REFOULÉ, F., Iniciación a la práctica de la teología, Op. cit., p. 178.
} 
Assim, o primeiro romance cristão, que são os Escritos pseudo-clementinos, e um amplo documento canônico-litúrgico datado em torno do ano 230, chamado Didascalia, exaltam a monarquia do bispo, sistema apto a evitar toda sorte de conflito no seio da comunidade eclesial:

\begin{abstract}
A massa dos crentes deve obedecer a um chefe único para poder, assim, viver na concórdia. Porque o regime que, à imitação da monarquia, se sustenta sobre o comando de um chefe único, leva, mediante a justa ordem, as pessoas a serem felizes na paz. Mas se todos quiserem mandar e recusam obedecer a um só chefe, são destinados a uma ruína inevitável por causa da divisão que reinará entre eles... se um só rei governasse toda a terra, não tendo mais nenhum motivo de fazer a guerra, se viveria em paz perpétua. No fim dos tempos, sobre os que forem julgados dignos da vida eterna, Deus estabelecerá um único rei para todo o universo, para fazer reinar, graças à monarquia, uma paz segura. A comunidade toda deve seguir, portanto, um só homem como guia e honrá-lo acima dos demais como imagem de Deus ${ }^{34}$.
\end{abstract}

Tal sistema, estimulando o paternalismo episcopal, traz consigo uma explícita infantilização dos leigos e leigas: "O bispo amará os leigos como filhos, os fará crescer e os animará com o zelo do seu amor, como (se faz) com os ovos para que nasçam os pintainhos, ou melhor, cuidará deles e os fará crescer como pintainhos até fazê-los tornar-se adultos" ${ }^{35}$. Nas Constituições Apostólicas - obra a partir da qual foi elaborada a Didascalia ${ }^{36}$ - os termos "laïkós" (leigo) e "laós" (povo, no sentido de multidão dos cristãos) aparecem com freqüência e servem, cada um a seu modo, para enfatizar essa relação de superioridade - inferioridade. O leigo torna-se uma figura submissa e dependente: "O leigo deve honrar o bom pastor, deve amá-lo e respeitá-lo como pai, senhor, mestre, sacerdote de Deus e guia da piedade." ${ }^{37}$ Deve submeter-se ao bispo como a um deus: "O leigo ame o leigo, ame também o bispo e o honre, respeite-o como a um pai, um senhor e um Deus, depois de Deus onipotente; porque ao bispo foi dito através dos apóstolos: 'Aquele que vos ouve a mim

\footnotetext{
${ }^{34}$ ESCRITOS PSEUDO-CLEMENTINOS: Homilia 3, 61-62.

${ }^{35}$ DIDASCALIA II, 20, 2.

${ }^{36}$ Cf. CATTANEO, E. I ministeri nella Chiesa antica. Testi patristici dei primi tre secoli. Milano: Paoline, 1997, pp. 597 ss.

${ }^{37}$ DIDASCALIA II, 20, 1.
} 
ouve e aquele que vos despreza despreza a mim e aquele que me enviou"" 38 . A honra devida ao bispo tanto pode significar "respeito" (assim no texto siríaco, que segue o texto grego: "Exortação ao povo para que honre o bispo") quanto "pagar os honorários" (assim os tradutores árabes e etíopes: "Os leigos devem oferecer dons à Igreja segundo as suas possibilidades").

Não obstante, é na exortação que se faz aos leigos para que dêem o dízimo ao bispo que se encontra uma das mais belas referências ao laicato: "Escutai, pois, leigos, Igreja escolhida de Deus: porque o primeiro povo (o povo hebreu) foi chamado de Igreja, mas vós (sois chamados) Igreja católica, santa e perfeita, sacerdócio real, povo santo, (adotado) como herdeiro, grande Igreja, esposa ornada para o Senhor Deus..." ${ }^{39}$. As alusões, como se percebe, são a 1 Pd 2,9-10, que remete a Ex 19,5.6, Dt 7,6; 14,2, e a Os 2,23, e a Ap 1,6, inspirado também em Ex 19,6.

Recorre-se tipologicamente também ao Antigo Testamento para definir e exaltar a figura do bispo: "O levita e o sumo sacerdote é o bispo; ele é o ministro do verbo e o mediador; é para vós também um doutor e pai depois de Deus... Honrai-o como Deus, porque o bispo ocupa para vós o lugar de Deus onipotente..." ${ }^{40}$. Esse bispo tem um poder imenso, celeste, divino. Reina sobre a alma e sobre o corpo. Por isso, deve ser amado como Deus ${ }^{41}$, recebe o dízimo em lugar de Deus e Deus abençoa o dizimista como se fosse o bispo ${ }^{42}$, não deve ser incomodado por ninguém: "Em todo lugar, portanto, (o bispo) seja honrado por todos os leigos, como convém, com dons, honras e o respeito do mundo. (Os leigos) terão grande confidência com os diáconos, não ficarão incomodando o chefe por qualquer motivo, mas lhe farão relatar aquilo que desejam pelos, isto é, pelos diáconos, porque ninguém pode aproximar-se do Senhor Deus onipotente senão por meio de Cristo..."43.

A supervalorização teológica e institucional do bispo caminha pari passu com uma desvalorização teológica e institucional dos leigos e leigas. À medida que cresce a autoridade do bispo, chegando às raias do arbítrio, o leigo torna-se uma figura dependente, submissa, passiva. Os leigos não podem pedir contas ao bispo de como adminstra: "É o Senhor Deus que lhe pedirá

\footnotetext{
${ }^{38}$ Ibidem.

${ }^{39}$ DIDASCALIA 2, 26.

${ }^{40}$ DIDASCALIA 2, 26,4ss.

${ }^{41}$ Cf. DIDASCALIA 2, 24, 4.

${ }^{42} \mathrm{Cf}$. DIDASCALIA 2, 34, 5-6.

${ }^{43}$ DIDASCALIA 2, 28, 5-6.
} 
contas, ele que lhe confiou este cargo e o julgou digno do sacerdócio de um tal nível" 4 . São como coisas nas mãos do seu senhor: "Ai daquele que, sendo apenas um vaso de barro, se atreve a discutir com o seu criador! Por acaso a argila vai dizer ao oleiro: "Que é isso que você está fazendo? Essa vasilha não tem cabo?" (Is 45,9-10) ${ }^{45}$. Esse estado de inferioridade é, porém, compensado pelo fato de os leigos possuírem bens deste mundo: "A vossa força são os bens deste mundo" 46 . Mas esses bens ser oferecidos a Deus na pessoa bispo: "Sejas fiel no apresentar os teus dons; não te afastes da Igreja... lança aquilo que tens nas mãos... porque isto é recolhido pelo bispo..." ${ }^{\text {47 }}$. Afinal, este tem direito à honra e ao honorário!

Essa eclesiologia repercute na própria ordenação do espaço físico. Nas igrejas, estabelece-se uma rígida separação entre clérigos e leigos: "Seja reservada aos presbíteros a parte da casa que está voltada para oriente. Entre eles seja colocada a sede ["cátedra" no Ocidente, "trono" no Oriente - n.d.a.] do bispo, e com ele se sentem os presbíteros. Os leigos sentem-se na outra parte da casa. De fato, convém que os presbíteros se sentem na parte da casa voltada para o Nascente, junto com o bispo, e os leigos [se sentem - n.d.a.] depois deles, e então as mulheres..." ${ }^{48}$. Até para o ato de levantar-se durante as orações, há uma ordem a ser respeitada: primeiro os presidentes; depois, os leigos e, por último, as mulheres ${ }^{49}$. $\mathrm{Na}$ administração do batismo, o leigo só participa, muito limitadamente, na preparação dos catecúmenos e, crescendo o batismo de crianças, como padrinhos e madrinhas. As mulheres leigas são proibidas de instruir e de batizar os homens ${ }^{50}$. Aliás, são proibidas de batizar qualquer pessoa...

A cristã "leiga" - esta palavra estará fora do vocabulário cristão por séculos ${ }^{51}$ - segundo as Constituições apostólicas, uma obra do fim do quarto século, está numa posição extremamente desconfortável, entre o homem (ordem natural) e Cristo (instituição positiva):

\footnotetext{
${ }^{44}$ DIDASCALIA II, 35, 4. "A você cabe dar; a ele, dispensar" (Ibidem, 2, 35, 3).

${ }^{45} \mathrm{Cf}$. DIDASCALIA 2, 36, 1; cf. Jr 18,6 e Is 45,9-10.

${ }^{46}$ Cf. DIDASCALIA 2, 36, 3.

${ }^{47}$ Cf. DIDASCALIA 2, 36, 3-6; cf. Ex 23,15; Mt 6,20.

${ }^{48}$ DIDASCALIA 2, 57, 3-5a. A menção da "casa" indica que a reunião não se dava num edifício específico, mas numa habitação privada, como a sala de $13 \times 5\left(65 \mathrm{~m}^{2}\right)$ descoberta nas escavações de Dura-Europos, na margem ocidental do Eufrates, no atual Iraque.

${ }^{49}$ Cf. DIDASCALIA 2, 57, 5.

${ }^{50} \mathrm{Cf}$. DIDASCALIA 3, 9.

${ }^{51}$ Cf. FAIVRE, A. I laici alle origini della Chiesa, Op. cit., p. 127.
} 
Quanto às mulheres que batizam, vos informamos do grave perigo a que se expõem aquelas que ousam agir desta maneira. Não aconselhamos comportar-se assim porque é incerto, ou melhor, porque é ilegal e ímpio. De fato, se a cabeça da mulher é o homem, é ele que eleito também para o sacerdócio; não é justo desprezar a criação e abandonar o que vem primeiro para ir em busca do corpo, que veio depois: porque a mulher é corpo do homem, tirada de sua costela, a ele submetida e dele distinta em vista da procriação. De fato, foi dito: 'Ele dominará sobre ti. Porque o homem é o cabeça da mulher, já que é a sua cabeça'. Se antes tínhamos proibido as mulheres ensinar, como poderíamos consentir que exerçam o sacerdócio contra a natureza? Porque esta aberração de instituir sacerdotisas para divindades femininas provém do ateísmo dos pagãos e não da instituição de Cristo ${ }^{52}$.

Não foi difícil - muito ao contrário - o sentido técnico (leigo é aquele que "não é" clérigo) deslizar para o sentido exclusivamente negativo: leigo é aquele que "é só" não-clérigo. A famosa informação do Kirchenlexikon, editado em 1891, que, no verbete "Laien" (leigos), remetia à palavra "Clerus" (clero), ${ }^{53}$ é significativa de toda uma mentalidade que só foi teoricamente superada na segunda metade do século XX. De fato, uma das tarefas que a chamada "teologia do laicato" assumiu foi justamente a de dar positividade ao conceito de leigo. O leigo é um cristão e, portanto, tudo o que é dito do cristão e da condição cristã em Lumen gentium II se aplica a ele; o leigo é um membro do povo de Deus; ainda que seja discutível ligar a palavra "leigo" à expressão laós toù Theoù (povo de Deus) ${ }^{54}$, o leigo, pela fé e pelos sacramentos da iniciação, é incorporado a Cristo e à Igreja, e participa da missão de Cristo, na Igreja e no mundo, como o descreve Lumen gentium 31.

\section{Uma hierarquia entre os leigos: os "idiotes" na base; os "laici" no topo}

Na Idade Média, a figura dos leigos passa por grandes transformações, em função do ambiente sociocultural, progressivamente cristão, da influência dos príncipes cristãos e dos formadores de opinião (bispos, teólogos, monges).

\footnotetext{
${ }^{52}$ CONSTITUIÇÕES APOSTÓLICAS 3, 9, 1-3.

53 Cf. Biographisch-Bibliographisches Kirchenlexikon oder Encyklopädie der katholischen Theologie und ihrer Hilfswissenschaften, Herder, Freiburg i. Breisgau, 1891, tomo VII, col. 1323. ${ }^{54} \mathrm{Cf}$. CAPPELLARI, M. Il trionfo della Santa Sede e della Chiesa contro gli assalti de' novatori, respinti e combattuti colle loro stesse armi. Roma: 1799 (citação da tradução francesa: tomo I, p. 18).
} 
Por um lado, prossegue aquela tendência, presente desde o século IV, de desvalorização do estado laical; pelo outro, registram-se momentos de apreço e de promoção dos leigos e leigas; no final do período, pode-se observar, em certas áreas, até mesmo o afirmar-se dos leigos e leigas como "cristãos e espirituais"

No período dos reinos bárbaros, distinguem-se duas categorias de fiéis: um grupo mais fervoroso, que vive à sombra dos mosteiros e das igrejas, num estado de "conversão" ou "penitência", e a maior parte do povo, que recebeu uma instrução religiosa mínima por ocasião da recepção dos sacramentos.

A massa do povo tem um nível cultural tão baixo que é comparado ao jumento, que não deve arar junto com o boi (cf. Dt 22,10). Chega-se mesmo a fazer derivar "laicus" (leigo) de "lapis, lapidis" (= pedra), "quia durus et extraneus a scientia litterarum" (porque duro e alheio ao conhecimento das letras). Por não dominar o latim, a língua da cultura clássica e da Igreja, o leigo é considerado "idiota, ae", ou "idiotes, ae", que, por maiores que sejam a boa vontade e o conhecimento da lexicografia e da semântica, não pode deixar de significar idiota, grosseiro, ignorante, sem letras ("illiteratus"). Foi neste contexto que o termo "leigo" adquiriu o sentido que, sobretudo entre nós, na linguagem corrente, é o predominante: a pessoa desinformada, que não é daquela área (de experiência e/ou conhecimento), "leiga no assunto".

De fato, na alta Idade Média, muito poucos estavam em condições de ler um texto em grego; até o latim e o domínio da escrita tornaram-se patrimônio exclusivo de um círculo restrito de pessoas de Igreja, os "ecclesiastici" (eclesiásticos) ou "clerici" (clérigos). "Clericus" tornou-se sinônimo de alfabetizado, enquanto "laicus", de analfabeto. "Leiga", na verdade, era, neste sentido, toda a sociedade altomedieval. Nem mesmo as classes dominantes, os nobres e os senhores, mostravam-se interessados na aprendizagem do latim e da escrita.

A hierarquia da Igreja, em todo caso, deu especial atenção aos nobres. Convertidos os nobres, convertido estaria o povo; bem formados os nobres, seria mais fácil cristianizar a vida social e política. A Igreja se dedicou por mais de dez séculos à formação de bons nobres, pois isso significava garantir para si, através das leis e sanções da "espada temporal", um bom povo. O cardeal Humberto explicitou muito bem esta lógica: os reis devem seguir os eclesiásticos; o povo deve seguir os seus reis para utilidade da Igreja e da pátria!

Os reis, de fato, eram formados com muito esmero. Para este fim, elaboraram-se os chamados Specula principum (literalmente, espelho dos prín-

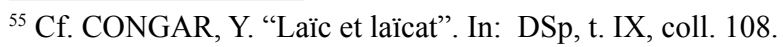


cipes), um manual de virtudes que os príncipes deviam incorporar para bem exercer seu "ministério", para o qual eram deputados mediante uma consagração ritual. Esses "ministros" tinham alguns deveres, o primeiro deles a defesa e a dilatação da Cristandade, apelando mesmo, se necessário, para guerras (missionárias) e cruzadas $^{56}$.

Os nobres passaram a ter cada vez mais influência na designação dos bispos: "As famílias nobres começaram a ser influentes, a ponto de determinar a escolha dos próprios bispos. Os príncipes arrogaram a si, para própria vantagem, o direito dos leigos da aprovação episcopal e o transformaram em direito de nomeação. Os grandes senhores feudais nomeavam mais da metade dos bispos feudais." Os "leigos", portanto, dos quais foram retirados, no contexto da Reforma Gregoriana, o poder de instalar bispos, abades, abadessas e párocos (costume tolerado nos séculos X e XI) ${ }^{57}$, não eram os leigos comuns, mas os "nobres": senhores feudais, reis, imperadores. ${ }^{58}$ A assim chama "luta pelas investiduras" foi, na verdade, um dos momentos mais agudos e graves para tirar a Igreja das mãos dos "leigos", isto é, dos senhores temporais, dos altos escalões da nobreza. ${ }^{59}$

\section{Quando a Igreja é a hierarquia, "in ecclesia nullus laicus"!}

Quando, num dado momento, difícil de precisar, a Igreja é identificada com a hierarquia, os leigos - da base ou do topo da pirâmide, não importa chegam ao fundo do poço eclesial: "in ecclesia nullus laicus" (na Igreja não há leigo). Esse fenômeno é raro entre teólogos e em manifestações do magistério, mas é (já foi mais) generalizado na opinião comum, dentro e fora da Igreja. Essa visão, na realidade, é historicamente condicionada por uma situação em que, por um lado, o clero se torna o único sujeito do agir, do poder e do saber na Igreja, e, pelo outro, o poder e a cultura na sociedade se identificam com a cultura e o poder da Igreja, isto é, nessa perspectiva, do clero.

${ }^{56}$ Cf. ERBA, A. M. "Storia del laico". In: ANCILLI, E. Dizionario di spiritualità dei laici. MILANO: Edizioni O.R., 1981, p. 375.

${ }^{57}$ SCOMAZZON, E. "I laici nella storia delle istituzioni di diritto canonico". In: ius canonicum. it, 31 luglio 2014.

${ }^{58}$ Cf. FISCHER-WOLLPERT, R. Léxico dos papas: de Pedro a João Paulo II. Petrópolis: Vozes, 1991, pp. 344-347.

${ }^{59}$ Cf. AA. VV. 100 punti caldi di storia della Chiesa. Milano: Edizioni Paoline, pp. 124ss. 
Entre o século do XII e o XIV, encontra-se certo número de textos onde, sob o nome Igreja, entende-se a hierarquia. "Tota Ecclesia", em Alexandre III (1105-1181), designa frequentemenete o episcopado. Os clérigos eram "as pessoas da santa Igreja”, como se dizia na Inglaterra e na França nos séculos XIII e XIV. Mesmo quando se considerava a Igreja como sociedade de fiéis, era nos clérigos que se pensava quando se usava a expressão "pessoas da Igreja": "Ecclesia dicitur duplice. Vel congregatio fidelium constans ad minus ex episcopo, presbytero, diacono et subdiacono; vel domus materialis..." (Diz-se Igreja em dois sentidos. Ou como congregação dos fiéis constando ao menos de bispo, presbítero, diácono e subdiácono; ou a casa material ${ }^{60}$ Mais tarde, Guilherme Amidani (ou de Cremona) (+1355), escreverá: “Accipitur Ecclesia pro potiori parte Ecclesiae, scilicet pro clericis seu pro universitate clericorum. Non quia layci non sunt ecclesiastici, immo sunt, sed quia non sunt ita nobiles in Ecclesia sicut clerici." (Toma-se a Igreja pela parte principal da Igreja, isto é, pelos clérigos ou pela totalidade dos clérigos. Não porque os leigos não sejam membros da Igreja, ao contrário, o são, mas porque não são tão nobres na Igreja como os clérigos). ${ }^{61}$

Naturalmente, entre os teólogos da plenitudo potestatis (plenitude do poder) papal, a assimilação da hierarquia à Igreja encontrava suma aplicação especial ao papa: "Summus Pontifex qui tenet apicem Ecclesiae et qui potest dici Ecclesia", ${ }^{62}$ escreve Egídio Romano (1243-1316) em seu De ecclesiastica potestate, professor de Giacomo da Viterbo (1301/1302), autor do De regimine Ecclesiae, considerado o primeiro tratado de eclesiologia. Para esses teóricos do poder eclesiástico ou da autoridade papal, o termo "Igreja" designa, muitas vezes, os clérigos, os sacerdotes, o papa: um uso do termo que era totalmente estranho aos Padres e à liturgia.

Congar diz sem pestanejar que, "num grande número de textos modernos, o termo 'Igreja' designa o governo sacerdotal, ou seja, simplesmente a instância romana deste governo, e se encontra distinta dos fiéis, dos homens, e situada fora deles, acima deles. Um só exemplo, entre a centena [sic] que se poderia aportar: "A Igreja é encarregada de apascentar o rebanho de Jesus Cristo." ${ }^{\prime 3}$

\footnotetext{
${ }^{60}$ MONETA CREMONENSIS. Summa adversus Catharos et Valdenses, Ed. Tommaso Agostino Ricchini. Roma: Nicolau e Marco Palearini, Typographia Palladis, 1743.lib. V, c. 8, § 3; apud CONGAR, Y. Jalons pour une théologie du laïcat, Op. cit., p. 71, nota 40.

${ }^{61} \mathrm{Cf}$. Ibidem.

${ }^{62} \mathrm{Cf}$. Ibidem.

${ }^{63}$ Cf. CONGAR, Y. Problèmes de l'autorité. Paris: Cerf, 1962, p. 169.
} 
A equivocada afirmação é de Mauro Cappellari, futuro papa Gregório XVI (1765-1846), ${ }^{64}$ no discurso preliminar à sua obra Trionfo della Santa Sede $e$ della Chiesa. Congar questiona: "Mas ela não é o próprio rebanho? Este deslizamento de vocabulário é grave. Primeiro, não é conforme nem ao uso da Escritura nem ao dos Padres nem ao da liturgia. Depois, corre o risco de "subtrair" a Igreja ao âmbito do homem espiritual a edificar." 65

Essa ideia permitiu o desenvolvimento de uma concepção do sacerdote como aquele que "rege" (do verbo latino 'regere', emparentado com o substantivo 'rex', rei) a paróquia, tendo o regimen, fazendo o ato de regere; de uma concepção do bispo e do papa como juízes; do papa como soberano, sendo o vigário de Cristo, "Rex regum et Dominus dominantium" (Rei dos reis e Senhor dos senhores); da Igreja como regina, magistra et domina (rainha, mestra e senhora).

À linguagem verbal juntou-se, desde muito cedo, a simbólica. A autoridade, sobretudo a autoridade suprema do papa, não só tomou, a partir do século XI, muitos elementos do vocabulário, mas também das insígnias, do cerimonial, do estilo e da ideologia da corte imperial. Esses elementos, às vezes, remontam ao próprio paganismo, mais precisamente - através da monarquia helenística de Alexandre Magno - ao paganismo persa do IV século a.C. O próprio título de Cúria assumido, em finais do século XI, pela administração papal é um empréstimo ao vocabulário secular. Contra esse estado de coisas se insurge São Bernardo: "Menos pompas e mais Evangelho ... Pareces sucessor não de Pedro, mas de Constantino."

Como a confirmar, "sub contrario", esta acepção - mas, na verdade, para eliminá-la - o papa Pio XII, no auge da "teologia do laicato", proferiu - diante dos cardeais criados no dia 20 de fevereiro de 1946 - aquela frase que, desde então, corre o mundo:

Sob este aspecto [da missão da Igreja na sociedade], Veneráveis Irmãos, os fiéis, e mais precisamente os leigos, se encontram na linha mais avançada da vida da Igreja; para eles a Igreja é o princípio vital da sociedade humana.

\footnotetext{
${ }^{64}$ Sobre este papa intransigente, reacionário e obscurantista, cf. MCBRIEN, R. P. Os papas. De São Pedro a João Paulo II. São Paulo: Loyola, 2000, pp. 343ss.

${ }^{65}$ CONGAR, Y. Problèmes de l'autorité, Op. cit., p. 169.

${ }^{66} \mathrm{Cf}$. Ibidem, p. 170. A referência é à famosa carta de São Bernardo ao papa Eugênio III, seu antigo discípulo, sob o nome de "De consideratione Libri Quinque Ad Eugenium Tertium", em: PL CLXXXII 727-808. "In his succesisti non Petro, sed Constantino" (nestas coisas, sucedeste não a Pedro, mas a Constantino) (Ibidem, IV, III, 6, p. 453).
} 
Por isso eles, especialmente eles, devem ter uma sempre mais clara consciência, não só de pertencer à Igreja, mas de ser a Igreja, quer dizer, a comunidade dos fiéis sobre a terra sob a condução do Chefe comum, o papa, e dos Bispos em comunhão com ele. Eles são a Igreja, e, por isso, desde os primeiros tempos da sua história, os fiéis, com o consenso dos seus Bispos, se têm unido em associações particulares, de acordo com as mais diversas manifestações da vida. E a Santa Sé nunca deixou de aprová-las e de louvá-las. ${ }^{67}$

\section{A Igreja, para o clero; o mundo, para os leigos}

No regime chamado de cristandade, "não havia um "mundo" verdadeiro e próprio fora da Igreja, e a palavra ecclesia significava tanto a sociedade temporal como a Igreja propriamente dita." ${ }^{68}$ Neste contexto de simbiose entre a Igreja e a sociedade, desenvolve-se uma concepção desconhecida na Igreja antiga: a ideia de uma função "própria" dos leigos. Não por acaso isso se deu naquele "outono da Idade Média" (título de célebre obra o escritor holandês Johan Huizinga) que foi o século $\mathrm{XII}^{69}$, semeadura daquilo que,

\footnotetext{
${ }^{67}$ PIO XII. Discorso ai nuovi cardinali, 20 febbraio 1946. A frase completa é: "Sotto questo aspetto, Venerabili Fratelli, i fedeli, e più precisamente i laici, si trovano nella linea più avanzata della vita della Chiesa; per loro la Chiesa è il principio vitale della società umana. Perciò essi, specialmente essi, debbono avere una sempre più chiara consapevolezza, non soltanto di appartenere alla Chiesa, ma di essere la Chiesa, vale a dire la comunità dei fedeli sulla terra sotto la condotta del Capo comune, il papa, e dei Vescovi in comunione con lui. Essi sono la Chiesa, e perciò fin dai primi tempi della sua storia, i fedeli, col consenso dei loro Vescovi, si sono uniti in associazioni particolari concernenti le più diverse manifestazioni della vita. E la Santa Sede non ha mai cessato di approvarle e di lodarle." (Sob este aspecto, Veneráveis Irmãos, os fiéis, e mais precisamente os leigos, se encontram na linha mais avançada da vida da Igreja; através deles a Igreja é o princípio vital da sociedade humana. Por isso eles, especialmente eles, devem ter uma consciência cada vez mais clara, não só de pertencer à Igreja, mas de ser a Igreja, quer dizer, a comunidade dos fiéis na terra sob a condução do chefe comum, o papa, e dos bispos em comunhão com ele. Eles são a Igreja, e por isso desde os primeiros tempos da sua história, os fiéis, com o consenso dos seus bispos, se uniram em associações particulares relativas às mais diversas manifestações da vida. E a Santa Sé nunca deixou de aprová-las e de louvá-las).

${ }^{68}$ CONGAR, Y. "Leigo". In: FRIES, H. (ed.). Dicionário de teologia. Conceitos fundamentais da teologia atual, III. São Paulo: Loyola, 1970, p. 132.

69 “'Os historiadores não têm dúvida. Em torno do século XII, que assinala uma daquelas viradas epocais que só raramente a história registra, constata-se um fato fundamental: ingressa no cenário da história um povo novo, mais dinâmico, com exigências próprias e intuições originais. O incremento demográfico, a introdução de novas técnicas, o desenvolvimento da agricultura, o crescimento do comércio, o despertar das cidades, a explosão do fenômeno associativo, a evolução da cultura e da arte - uma aceleração que vai da economia à religião - dão vida a um
} 
séculos adiante, será chamado Modernidade, quando o leigo, virado "laïc" (laico, laicista), se voltará contra o clero em nome da "laïcité" (laicidade, laicismo). É só esperar para ver.

\subsection{O Decreto de Graciano (1140)}

Coube a um dos pais do direito canônico formulá-la com meridiana clareza:

Há dois gêneros de cristãos. $O$ primeiro gênero, tomado para o serviço divino, e dedicado à contemplação e à oração, convém renunciar a todo ruído das coisas temporais, pois são clérigos, e consagrados a Deus, ou

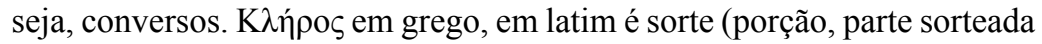
em herança). Daí que deste modo os homens chamados clérigos são escolhidos por sorte. Pois Deus escolheu a todos eles como seus. Estes, portanto, são reis, isto é, regem a si e aos outros pelas virtudes, e assim têm em Deus o reino. E é isso que a coroa na cabeça indica. $\mathrm{O}$ outro gênero de cristãos é o dos que são leigos. $\Lambda \alpha$ ós, com efeito, é o povo. É-lhes permitido possuir bens temporais, mas apenas para o uso. Pois nada é mais miserável que desprezar a Deus por causa do dinheiro. É-lhes concedido casar-se, cultivar a terra, dirimir por julgamento, pleitear causas, depor as oferendas sobre o altar, entregar os dízimos, e, assim, poderão salvar-se se, todavia, evitarem os vícios, fazendo o bem. ${ }^{70}$

contexto social mais dinâmico e aberto. Com a criação das primeiras universidades, nos séculos XI e XII (1088: Bologna; 1122: Padova; 1180: Paris; 1218: Salamanca; 1249: Cambridge, etc.), tanto professores quanto alunos - leigos, é claro - dispõem de um espaço mais amplo para sua formação cultural e passam a ter não só uma influência notável sobre a legislação, mas também uma participação mais efetiva nas lutas ideológicas e religiosas, reservadas antes quase que exclusivamente aos religiosos e clérigos." (ALMEIDA, A. J. Leigos em quê? Uma abordagem histórica. São Paulo: Paulinas, 2006).

70 "Duo sunt genera christianorum. Est autem genus unum, quod mancipatum divino officio, et deditum contemplationi et orationi, ab omni strepitu temporalium, cessare convenit, ut sunt clerici,

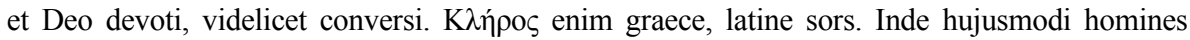
vocantur clerici, id est sorte electi. Omnes enim Deus in suos elegit. Hi namque sunt reges, id est se et alios regentes virtutibus, et ita in Deo regnum habent. Et hoc designat corona in capite. Aliud vero est genus christianorum ut sunt laici. $\Lambda \alpha$ ó $\varsigma$ enim est populus. His licet temporalia possidere, sed non nisi ad usum. Nihil enim miserius est quam propter nummum Deum contemnere. His concessum est uxorem ducere, terram colere, inter virum et virum judicare, causas agere, oblationes super altaria ponere, decimas reddere, et ita salvari poterunt, si vitia tamen benefaciendo evitaverint." (DECRETUM MAGISTRI GRATIANI, C. 7 C. XII, q. I, In: FRIEDBERG, E. (ed.). Corpus Iuris Canonici, I. Leipzig: Bernhardt Tauchnitz, 1989, p. 678). 
Eram os tipos de cristãos que restavam diante da clericalização dos monges, da monacalização do clero e da secularização dos leigos:

Monge é o nome da perfeição e clérigo o nome do ofício, que não devem ter senão os perfeitos, por isso o estado clercal propriamente pertence aos monges, pois eles são... imitadores dos Apóstolos... Com efeito, é o que fazem quando se tornam monges, são marcados pelo sinal da perfeição, pelo sinal clerical, que é a coroa, acedem à porção de Deus e se tornam herança de Deus. ${ }^{71}$

Poucos anos depois, Humberto da Silva Cândida escrevia que os leigos deviam ocupar-se só das realidades mundanas, enquanto dos negócios da Igreja cuidavam só os clérigos: "Os leigos disponham e provejam só as suas coisas, isto é, as temporais; os clérigos, somente as suas, isto é, os assuntos eclesiásticos." 72

Entre os clérigos, destacam-se os bispos, em cujo vértice está o papa, a quem Cristo conferiu, em Pedro, o poder de ligar e desligar na terra (cf. Mt 16,19); entre os leigos, destacam-se os nobres - mormente os reis e os imperadores - para cuja conversão e formação a Igreja dedicou suas melhores energias, de modo que as estruturas temporais estivessem diretamente a serviço dos seus fins de culto, moralidade, salvação. Os leigos devem, portanto, prestar obediência às autoridades temporais e às autoridades espirituais: "sicut regum est ecclesiasticos sequi, sic laicorum quoque reges suos ad utilitatem ecclesiae et patriae" 73 (assim como é próprio dos reis seguir os eclesiásticos, é próprio dos leigos [seguir] os seus reis para utilidade da igreja e da pátria) Essa divisão em dois gêneros consagrou, de um lado, a "clericalização" da Igreja, e, do outro, à sujeição do império cristão ao poder espiritual da Igreja, à luz da teoria das "duas espadas": a espiritual, nas mãos da Igreja; a outra, nas mãos dos leigos, a serviço da Igreja!

\footnotetext{
71 "Monachus est nomen perfectionis et clericus est nomen officii, quod non debent habere nisi perfecti, idcirco clericatus proprie pertinet ad monachos, ipsi enim sunt... imitatores Apostolorum... Hinc est quod quando fiunt monachi, insigniuntur perfectionis signo, id est clericali, quod est corona, quia tunc intrant sortem Dei et fiunt haereditas Dei.” (IBIDEM)

72 "Laici sua tantum, id est saecularia; clerici autem sua tantum, id est ecclesiastica negotia, disponant et provideant." (SILVA CANDIDA, H. Adversus simoniacos libri tres (III, 9): PL 143, p. 1153.

${ }^{73}$ IBIDEM, III, 21.
} 


\subsection{O nascimento e a hegemonia dos "laïcs"}

Tudo começou a mudar no século XIII, quando começou a afirmar-se o "esprit laïque" (espírito laico, laicista) ${ }^{74}$. Na verdade, trata de um processo longo e extremamente complexo, cujos elementos mais importantes apenas acenamos aqui: a) o nascimento do Estado moderno como "potência pública", dotado de um poder soberano e independente de qualquer outro poder, sobretudo do poder religioso, o que provocou inúmeros conflitos, criando um estado de hostilidade geral contra o clero $^{75}$; b) um processo de laicização (ou secularização) do pensamento e da vida, que consistiu, primeiro, na progressiva separação das realidades mundanas da religião cristã e na libertação da sua influência e tutela tanto no âmbito do pensamento (cultura, ciência, direito, moral, política, filosofia) como no dos comportamentos; depois, na afirmação da autonomia e da independência das realidades humanas seja em relação à Igreja (sua autoridade, suas doutrinas e leis morais) seja em relação ao próprio Deus; finalmente, na exclusão da religião de todos os âmbitos da vida humana e, em seu ápice filosófico e religioso-político, na negação de Deus e na luta contra a Igreja e o cristianismo; c) a laicização da escola e a separação entre Igreja e Estado como meios para instaurar, nas suas versões mais radicais, este reino da irreligião. A França foi o país em que mais a laicização assumiu um caráter violentamente antirreligioso e anti-cristão, particularmente durante a Revolução Francesa e na III ${ }^{\mathrm{a}}$ República. Exatamente neste período (18791905) os "laïcs" (laicos) - foi assim que começaram a autodenominar-se - obtiveram a maioria no Parlamento e governaram a França. Naquela conjuntura, os "laïcs" (laicos) mais famosos foram Léon Gambetta (1838-1882), Jules Ferry (1832-1893), Georges Clémenceau (1841-1929), Pierre Waldeck-Rousseau (1846-1904), Émile Combes (1835-1921), René Viviani (1862-1925).

\subsection{Atitude da Igreja católica}

Pela primeira vez em sua história, a Igreja se viu diante de um homem autonomamente "homem" e de um mundo plenamente "mundo". ${ }^{76}$ Não só perdeu o lugar que ocupara na longa estação da cristandade - simbolicamente do Edito de

\footnotetext{
${ }^{74}$ Cf. LAGARDE, G. La naissance de l'esprit läque au déclin du Moyen Age. Paris - Louvain: Nauwelaerts, 1956ss.

${ }^{75}$ Cf. “Laici, laicità, laicismo”. La Civiltà Cattolica, editoriale, quaderno no 3609 (4 novembre 2000).

${ }^{76}$ Cf. CONGAR, Y. "Leigo”. In: FRIES, H. (ed.). Dicionário de teologia. Conceitos fundamentais da teologia atual, Op. cit., p. 133.
} 
Tessalônica (381) à Revolução Francesa (1789) - mas viu-se perdida num mundo que não era mais seu. A instituição, de modo geral, fechou-se ressentida sobre si mesma, defendendo-se dos golpes que lhe vinham da sociedade e do Estado, e, sobretudo, acusando e atacando a nova cultura e seus representantes. A atitude dos papas foi de condenação: Pio IX condena a separação entre Estado e Igreja (proposição 55 do Syllabus, 1864) e o fim da religião católica como religião do Estado (proposição 76 do Syllabus); Leão XIII declara absurda a opinião dos que pensam que as leis divinas devem regular a vida e a conduta dos indivíduos, mas não a dos Estados; que, por isso, é permitido, nos negócios públicos, afastar-se das ordens de Deus e legislar sem levá-Lo em conta (Immortale Dei, 1885); Pio $\mathrm{X}$ afirma que a separação entre Estado e Igreja é uma "tese absolutamente falsa e um erro assaz pernicioso", porque é injurioso diante de Deus, Fundador das sociedades humanas; porque nega a ordem sobrenatural, limitando a ação do Estado à obtenção da prosperidade pública; porque subverte a ordem estabelecida por Deus, que exige uma harmoniosa concórdia entre a sociedade religiosa e a sociedade civil (Vehementer nos, 1906); Pio XI aceita um estatuto legal da Igreja na França, mas enfatiza que "todas as vezes que por "laicidade" se entende um sentimento ou uma intenção contrários a Deus e à religião, Nós reprovamos totalmente esta "laicidade" e declaramos abertamente que deve ser reprovada" (Maximam gravissimamque, 1924); além disso, ao instituir a festa de Cristo Rei, afirma que "a peste da nossa época é o laicismo, como é chamado, com os seus erros e as suas empresas criminosas.” (Quas primas, 1925)

\section{O leigo entre submissão e independência diante da hierarquia}

Aos poucos, porém, foi-se percebendo que "uma Igreja entricheirada na defesa das suas prerrogativas e das estruturas hierárquicas se punha em condição de deixar que a sociedade civil se construísse segundo parâmetros que teriam tornado sempre menos significativa a presença da própria Igreja no mundo (...) Continuar a atacar não bastava. Era necessário dar lugar àqueles que imersos nas coisas do mundo, teriam podido constituir uma ponte para reaproximar a igreja e a sociedade civil. Delineava-se, deste modo, a valorização daqueles que, até este momento, tinham sido considerados cristãos, sim, mas de segundo nível com respeito ao clero e aos religiosos, e ateus potenciais dada a sua condição vital." ${ }^{77}$ Leigos ilustres assumem um posto de vanguarda

${ }^{77}$ CANOBBIO, G. Laici o Cristiani? Elementi storico-sistematici per una descrizione del cristiano laico. Brescia: Morcelliana, 1992, p. 177. 
na polêmica contra as ideologias anticatólicas: François-René de Chateaubriand, com Génie du christianisme (1802) e Martyrs (1809); J. A. Von Diessbach, no apostolado da boa imprensa; os discípulos famosos do redentorista Clemens M. Hofbauer (1820): F. Schlegel, A. Müller, Cl. Brentano, F. Von Baader, J. F. Schlosser e outros; Frederico Ozanam (1853), fundador da Sociedade de São Vicente de Paulo. No âmbito propriamente político, outros leigos se destacam como defensores da ação da Igreja contra o laicismo dos Estados modernos: o irlandês Daniel O'Connel (1847); o alemão Joseph Görres (1848); o espanhol J. Donoso Cortés (1853); o conde Charles de Montalembert (1870); com eles, entram em cena os precursores da doutrina social da Igreja: Armand de Melun (1877); Léon Harmel (1915). No mundo da ciência, temos o físico italiano Alessandro Volta (1827) e o químico Louis Pasteur (1895). Na literatura, um por todos: Alessandro Manzoni, com suas Osservazioni sulla morale cattolica (1819) e sua obra-prima Promessi Sposi (Os noivos, 1827). A Ação Católica, que vem à luz na segunda metade do século XIX, inaugurará um novo modelo de apostolado, voltado, ao mesmo tempo, à renovação da sociedade $\mathrm{e}$ à formação espiritual e cultural de seus membros.

Nesse contexto, vai-se esboçando o projeto de uma "nova cristandade", sentido vagamente por muitos e elaborado sistematicamente por J. Maritain em sua obra Humanisme intégral. Problèmes temporels et spirituels d'une nouvelle chrétienté, publicado em 1936. Maritain distinguia a atividade dos cristãos em três planos - espiritual, temporal e misto - sendo o primeiro reservado à Igreja, no sentido de hierarquia, e o segundo aos leigos. ${ }^{78}$ Dez anos depois, surgia a "teologia das realidades terrestres", ${ }^{79}$ que buscava superar a rígida separação entre ordem natural e sobrenatural e, consequentemente, o valor teológico das realidades mundanas, o que abria a possibilidade de um engajamento dos cristãos em vista de uma espiritualização do mundo. Surge um sem-número de iniciativas para reconquistar as massas operárias descristianizadas ${ }^{80}$ : padres operários, Mission de France, a Juventude Operária Católica; Pio XI, o "Papa da Ação Católica”, indica, na encíclica Quadragesimo anno (1931), que “os primeiros e imediatos apóstolos dos operários devem ser os operários; os apóstolos dos artistas e comerciantes devem sair dentre eles."

\footnotetext{
${ }^{78}$ Cf. CAMPANILI, G. L'utopia della nuova cristianità. Introduzione al pensiero di J. Maritain. Brescia: Morcelliana, 1975.

${ }^{79}$ Cf. THILS, G. Théologie des réalités terrestres. I. Préludes. Paris: Desclée de Brower, 1946. ${ }^{80}$ Cf. DANIEL, Y. - GODIN, H. La France pays de mission? Paris: Édition de l'Abeille, 1943; GUASCO, M. Y. Daniel: contributo per una biografia. In: MELLONI, A. (ed.), Tutto è grazia. In omaggio a Giuseppe Ruggieri. Milano: Jaca Book, 2010, pp. 95-114.
} 
$\mathrm{Na}$ verdade, as circunstâncias e as necessidades da missão estão na origem da valorização do laicato de dois séculos para cá. Um lugar particular coube à Ação Católica: se, por um lado, foi concebida como a "longa manus" (longa mão) da hierarquia, pelo outro, se tornou um espaço de maturação de uma consciência eclesial e social de um sem-número de leigos e leigas. Além das distinções - nem sempre adequadamente elaboradas - entre natural e sobrenatural, atuação na Igreja e atuação no mundo, agir como cristão e agir enquanto cristão, o pano de fundo no qual se desenvolve uma atenção particular à função dos leigos em relação ao mundo é o debate sobre o modo de realizar a missão, onde se contrapunham duas visões, que, em âmbito teológico, foram chamadas de 'encarnacionista' e 'escatologista' ${ }^{81}$, com seus desdobramentos numa diversa visão da espiritualidade, do 'mundo', do Reino de Deus e do papel dos leigos.

\section{O mundo "lugar teológico" da vida cristã dos leigos e leigas}

A superação da doutrina das duas ordens (ou dos dois planos) - natural e sobrenatural - levava a sublinhar a unidade do "plano de Deus", que consiste em levar o mundo - criação de Deus - à sua plena realização em Deus. Leigos, pastores e teólogos, compartilhando o mesmo ideal da transformação do mundo segundo o Evangelho, foram vislumbrando a unidade na diversidade entre espiritual e temporal. "O espiritual, para o cristão, é, a rigor, a presença na nossa vida da vida eterna.... Mas esta vida eterna "é ela mesma carnal" e não se oferece a nós comumente que através dessas atividades naturais... Não temos que levar o espiritual ao temporal, ele já está lá; nosso papel é descobri-lo e de fazê-lo viver, de comungá-lo onde ele está. O temporal em sua totalidade é o sacramento do Reino de Deus." ${ }^{82}$ Não há, propriamente falando, diz o mesmo autor mais adiante, "duas histórias estranhas uma à outra, a história sagrada e a história profana. Há uma única história, a da humanidade a caminho do Reino de Deus... Da mesma forma que recusa a separação entre esses dois mundos, a Igreja afirma sua vigorosa distinção. É necessário precisar sem cessar uma e outra, e as manter juntas." 83

\footnotetext{
${ }^{81} \mathrm{Cf}$. BESRET, B. Incarnation ou Eschatologie? Contribution à l'histoire du vocabulaire religieux contemporain 1935-1955. Paris: Cerf, 1964.

${ }^{82}$ MOUNIER, E. Feu la chrétienté. Paris: Seuil, 1950, p. 246.

${ }^{83}$ IBIDEM, p. 260.
} 
Evidentemente, não se podia esquecer que Igreja e mundo não se identificam, porque, em relação a eles, a função real de Cristo se exerce de dois modos diversos: a mediação do 'poder', realizada pela hierarquia em vista da constituição do povo de fiéis; a mediação da 'forma de vida', atuada pelo conjunto do povo eclesial em relação ao mundo.

Delineia-se, neste novo contexto teológico, uma nova visão do leigo cristão, na qual adquire valência positiva o mundo, a realidade, o ambiente em que ele vive. O leigo passa a ser visto como o cristão para o qual as coisas existem; o lugar de vida é visto como o lugar de santificação. De uma espiritualidade de "fuga do mundo" se passa a uma espiritualidade de "encarnação no mundo", visto como criação de Deus encaminhado com a Igreja ao seu cumprimento escatológico no Reino de Deus.

\section{O "proprium" dos leigos numa Igreja em diálogo com o mundo}

As últimas três concepções do laicato - longa mão da hierarquia, o mundo para os leigos, o mundo lugar teológico da vida cristã dos leigos prepararam o Concílio Vaticano II, no qual, pela primeira vez na bimilenar história da Igreja, se presta ampla atenção à identidade e ao papel dos leigos tanto na Igreja como no mundo. O pano de fundo geral é a concepção conciliar da Igreja e do mundo no horizonte do Reino de Deus.

O Concílio abandona a contraposição entre a Igreja e o mundo: “As alegrias e as esperanças, as tristezas e as angústias dos homens de hoje, sobretudo dos pobres e de todos os que sofrem, são também as alegrias e as esperanças, as tristezas e as angústias dos discípulos de Cristo. Não se encontra nada verdadeiramente humano que não lhes ressoe no coração... A comunidade cristã se sente verdadeiramente solidária com o gênero humano e com sua história." (GS 1).

A Igreja - comunidade de "homens que, reunidos em Cristo, são dirigidos pelo Espírito Santo na sua peregrinação para o Reino do Pai” (Ibidem) - não pode ser considerada "à parte", mas entretecida com a humanidade. A missão não consiste só no anúncio do Evangelho, com toda a densidade desta expressão, mas também como assunção, purificação e elevação de tudo o que já existe em todos os povos e culturas (cf. LG 13).

Igreja e mundo, porém, não se confundem; são distintos e diferentes. Esta distinção, porém, não é separação nem contraposição, pois a Igreja, quando se distingue da humanidade, não se opõe a ela, ao contrário, se une a ela. Movida 
pelo mesmo amor de Deus (cf. Jo 3,16-17), a Igreja tem consciência de uma missão que a transcende, de um anúncio a ser difundido, do mandato missionário, do dever da evangelização. O nome deste impulso interior de caridade, que tende a se tornar dom exterior, é "diálogo", diz Paulo VI, na Ecclesiam suam, a encíclica programática de seu pontificado: a Igreja "deve entrar em diálogo com o mundo em que vive; a Igreja se faz palavra; a Igreja se faz mensagem; a Igreja se faz diálogo" (Ecclesiam suam 38); mais precisamente, "colloquium salutis" (diálogo de salvação). (cf. nn. 73-79).

Os leigos são chamados e destinados à missão-que éúnica e a mesma para todos - não pela hierarquia, mas pelo próprio Senhor, através do batismo e da confirmação (cf. LG 33); eles a realizam, contudo, segundo a "índole secular", que lhes é própria e peculiar (propria et peculiaris) - portanto, não exclusiva - pois "é próprio dos leigos (laicorum est), por sua própria vocação, procurar o Reino de Deus exercendo funções temporais e ordenando-as segundo Deus. Vivem no século, isto é, em todos e em cada um dos ofícios do mundo. Vivem nas condições ordinárias da vida familiar e social, pelas quais sua existência é como que tecida. Lá são chamados por Deus para que, exercendo seu próprio ofício guiados pelo espírito evangélico, a modo de fermento, de dentro, contribuam para a santificação do mundo. E assim manifestam Cristo aos outros, especialmente pelo testemunho de sua vida resplandecente em fé, esperança e caridade. A eles, portanto, cabe de maneira especial, iluminar e ordenar de tal modo todas as coisas temporais, às quais estão intimamente unidos, que elas continuamente se façam e cresçam segundo Cristo, para louvor do Criador e Redentor." (esta assim em LG 31).

A questão foi retomada no Sínodo sobre a "Vocação e missão dos leigos na Igreja e no mundo" (1987), em que se contrapuseram duas tendências na reflexão teológica sobre o leigo: a que insistia na índole secular como o proprium do leigo e a que propugnava pela superação do binômio "hierarquia - laicato" pelo binômio "comunidade - carismas e ministérios", ao mesmo tempo em que relia a categoria de "secularidade", aplicando-a ao mundo e à Igreja. Prevaleceu a tendência literalmente conciliar. Os Padres sinodais afirmam na proposição 39: "A índole secular do fiel leigo não deve, pois, definir-se apenas em sentido sociológico, mas sobretudo em sentido teológico. A característica secular é vista à luz do ato criador e redentor de Deus, que confiou o mundo aos homens e às mulheres, para tomarem parte na obra da criação, libertarem a mesma criação da influência do pecado e santificarem a si mesmos no matrimônio ou na vida celibatária, na família, no emprego e nas 
várias atividades sociais". A Christifideles laici, por sua vez, ainda que afirme a "igualdade" e a "dimensão secular" de todos os membros do povo de Deus, rebate: "Mas a comum dignidade batismal assume no fiel leigo uma modalidade que o distingue, sem todavia o separar, do presbítero, do religioso e da religiosa." O Concílio Vaticano II apontou a índole secular como sendo essa modalidade: "A índole secular é própria e peculiar dos leigos." (ChrL 15).

\section{Uma "comunidade de iguais" dotada de "carismas e ministé- rios" diferentes a serviço do Reino de Deus}

O Vaticano II afirma a igualdade fundamental de todos os membros da Igreja em virtude dos sacramentos da iniciação:

Um é pois o povo eleito de Deus: 'um só Senhor, uma só fé, um só batismo' (Ef 4,5). Comum a dignidade dos membros pela regeneração em Cristo. Comum a graça de filhos. Comum a vocação à perfeição. Uma só a salvação, uma só a esperança e indivisa a caridade. Não, há, pois, em Cristo e na Igreja, nenhuma desigualdade em vista de raça ou nação, condição social ou sexo, porquanto 'não há judeu ou grego, não há servo ou livre, não há varão ou mulher, porque todos vós sois um em Cristo Jesus' (Gl 3,28; cf. Cl 3,11).(LG 31).

Ao mesmo tempo, o Concílio afirma que a "santa Igreja é estruturada e regida com admirável variedade" (Ibidem): variedade de carismas, de serviços, de ministérios, de vocações, de condições de vida, etc. Coube sobretudo a Congar, na década dos setentas, propondo uma síntese virtuosa entre essas duas afirmações e, consequentemente, a superação do esquema hierarquia - laicato (que é visível no Concílio) pelo esquema comunidade - carismas, serviços e ministérios (igualmente presente no Concílio, mas não tão visível). "O batismo aparece como constitutivo de toda a dignidade cristã, princípio da consciência missionária bem como das responsabilidades cristãs no mundo. A Igreja é uma comunidade construída por um grande número de serviços." ${ }^{84}$

Apesar de, em sua origem, estar voltada tanto para a vida da Igreja quanto para sua missão, de fato esta teologia desempenhou importante papel na valorização dos leigos seja na edificação das comunidades seja na sua projeção missionária, especialmente naquelas situações em que o clero é escasso e os

${ }^{84}$ CONGAR, Y. Ministeri e comunione ecclesiale, Op. cit., p. 22. 
problemas sociais, desafiadores. Na América Latina, por exemplo, houve uma verdadeira explosão de serviços e ministérios, o que mereceu, primeiro, a atenção do Sínodo sobre a Evangelização no mundo contemporâneo, de 1974, da exortação sinodal Evangelii nuntiandi, de 1975, e, depois, da Conferência de Puebla, em 1979.

Ao risco de esta teologia deixar na sombra a "índole secular" dos leigos respondia-se fundamentalmente de duas maneiras: estendendo a "secularidade" à Igreja toda e afirmando a "plenitude" da secularidade nos leigos. Citrini, por exemplo, argumenta: "Em toda existência cristã imbricam-se secularidade e sacralidade; toda vocação cristã é mesclada de Igreja e de mundo. A figura hipotética de um "leigo puro", maximamente fiel a uma vocação de secularidade, é impossível, e não pode ser ponto de referência senão de preocupações reivindicatórias desclericalizantes... Como, vice-versa, é impossível uma figura de dedicação ao Reino que emargine totalmente a secularidade numa "fuga mundi" radicalizada além dos limites da fantasia. Se é verdade que existem diversidades e divisões de competências e responsabilidades também no sentido de um diverso engajamento com a secularidade e com a sacralidade, é pernicioso conceber tudo isso como uma repartição substancialmente adequada, que apenas contingências da vida se encarregariam de tornar aproximativa. Toda vocação cristã, dizíamos, é imbricada de Igreja e mundo: e seria perigoso (e nem sempre foi evitado) atribuir ao clero "em feudo" a Igreja, e ao laicado "em feudo" o mundo..." 85

O prof. Giuseppe Lazzati, ao contrário, insistia na "índole secular" como o "proprium" do leigo: este, para ele, "é o homem batizado que, enquanto homem, dedica-se, como batizado, à construção da cidade do homem. Ele, enquanto batizado, dedica-se, como homem, ou seja, como construtor da cidade do homem, à construção da Igreja e à sua missão evangelizadora."86 Segundo Lazzati, "na eventualidade que o caminho da teologia levasse à convicção geral de dever ver na laicidade um carisma pertencente a toda a Igreja, a própria laicidade permaneceria 'especificamente daqueles que hoje chamamos "os leigos" "87, pois ela é "plena" nos leigos e nas leigas.

\footnotetext{
${ }^{85}$ CITRINI, T. "Teologia dei ministeri e tensioni costituzionali dell'ecclesiologia". In: La Scuola Cattolica 104 (1976), p. 501.

${ }^{86}$ LAZZATI, G. Il laico. Roma: AVE, 1986, p. 17.

${ }^{87}$ MASTANTUONO, A. "Il cammino della laicità. La proposta di Lazzati". In: Movimento di Impegno Educativo di A.C. Proposta educativa 2 (2009), p. 54.
} 


\section{Os leigos como rosto simbólico da Igreja "encarnada"}

Ultimamente se está propondo um novo modelo de compreensão dos leigos e do laicato, na tentativa de ajudar a Igreja e a reflexão teológica a sair das recorrentes limitações e inadequações que marcam a história das interpretações desta figura eclesial que representa a esmagadora maioria dos cristãos e cristãs.

A Igreja tem uma dimensão de memória da origem, a prospecção do futuro e de presença na história que conotam a sua identidade e a sua missão em sua globalidade e em cada um dos seus membros. As diversas vocações eclesiais [o autor pensa no esquema tripartido "hierarquia - religiosos leigos"] evidenciam uma ou outra dessas dimensões: os ministros ordenados, a memória da origem; as várias modalidades de vida consagrada, a prospeção do futuro; as vocações laicais, a presença na história a serviço do Reino. ${ }^{88}$ Mais precisamente: "as vocações dos leigos cristãos têm em comum a tarefa de evocar e atuar 'simbolicamente' a extroversão originária da Igreja (a Igreja, com efeito, vive para o 'mundo' sob o modelo e por mandato de Jesus, que introduz o Reino de Deus)." ${ }^{89}$ Não meramente por uma razão sociológica, mas em última análise por uma razão teológica:

cada vocação cristã se configura na sua concretude mediante as conjunturas históricas nas quais entra em jogo a liberdade da pessoa. O modelamento da Igreja por parte do Espírito se atua mediante o jogo das liberdades, de modo que a sua missão se realiza através do concreto configurar-se das histórias pessoais. A Igreja não é para si, mas para o mundo, a fim de que este realize o seu destino, que consiste no cumprimento de toda a realidade em Cristo. A relação entre memória da origem (ministério ordenado), presença na história (leigos) e antecipação do éschaton (vida consagrada) historicamente foi articulado dando prevalência a um ou a outro, muitas

\footnotetext{
${ }^{88}$ Substituir o binômio hierarquia-laicato pelo trinômio hierarquia-laicato-religiosos de per si não representa nenhum avanço eclesiologicamente. Mas sair das estreitezas do binômio hierarquia-laicato e, ao mesmo tempo, trabalhar o binômio laicato-religiosos, é, sem dúvida, um ganho: "Até agora na Igreja prevalecera a relação clero-leigos e, portanto, o poder, enquanto, hoje, deveria prevalecer a dialética religiosos-leigos, porque, segundo a constituição [Lumen gentium - n.d.a.], os religiosos chamam a atenção para a transcendêncioa, enquanto os leigos, a encarnação" (ZIVIANI, G. Luigi Sartori a colloquio con Giampietro Ziviani. Una mentalità ecumênica. Milano: Ancora, 2006, p. 43).

${ }^{89}$ CANOBBIO, G. "La riflessione teologica sui laici dal Concilio a oggi”. In: NAVARRO, L. PUIG, F. (ed.). Il fedele laico. Realtà e prospettive. Op. cit., p. 32.
} 
vezes em dependência das conjunturas históricas e do modelo cristológico que se assumia... Nenhuma delas pode faltar, sob pena de empobrecer a missão eclesial. ${ }^{90}$

\section{Considerações finais}

As definições e descrições de leigo aqui repassadas talvez não recolham todos os significados que o termo veiculou ao longo da história do Ocidente.

Essas concepções foram apresentados em sucessão histórica. Isso, porém, não significa que sentidos antigos não sobrevivam em contextos novos, que conceitos diferentes (e até antagônicos) não coexistam num mesmo momento, que aspectos de um conceito sejam integrados em outros, que compreensões aparentemente superadas permaneçam poderosamente vivas em franjas da memória coletiva ou em correntes de pensamento refratárias ao diferente, ao desenvolvimento e à inovação.

Especialmente duas situações chamam a atenção. A primeira é o Novo Testamento não usar a palavra "leigo". A segunda é a renitente afirmação do caráter secular do leigo.

O Novo Testamento não é um testemunho entre tantos. É "regra suprema da fé" (DV 21). A volta às fontes e a desboberta de uma eclesiologia de totalidade e da estrutura também carismática da Igreja, que desembocaram no Vaticano II, tornaram possível a chamada "teologia dos ministérios", que floresceu nas décadas dos setenta e oitenta, e foi amplamente recebida (ainda que, às vezes, com reparos e restrições) até em pronunciamentos magisteriais. É difícil não ver na leitura da estrutura social da Igreja como 'comunidade dotada de uma pluralidade de carismas e ministérios' que emergiu na teologia contemporânea uma proximidade conatural com a eclesiologia e a teologia dos ministérios paulinas (pense-se em Rm 12,3-8; 1Cor 12,1-30; Ef 3,7; 1Tm 4,14). Às vezes, fica-se com a impressão que a teologia dos ministérios, ressuscitada nos anos setentas e combatida nos anos oitentas, sobretudo por sua impostação da questão da secularidade, fale da estrutura da Igreja; e que a outra (chamemo-la de a "teologia do laicato"), que trabalha com o 'binômio' hierarquia-laicato, por mais antiga, vulgada e persistente que seja, fale da conjuntura que a estrutura social da Igreja tomou "ab antiquo" (desde antigamente), mas não seja nem a melhor nem a única nem a exclusiva expressão do que foi divinamente instituído. O termo "leigo", na verdade, só entrou no vocabulário

${ }^{90}$ Ibidem. 
cristão quando, sociologicamente, dentro da Igreja, o grupo social "clero", com um perfil claro e prerrogativas exclusivas, que se tornou necessário dizer os "demais". Os outros, os demais, os restantes receberam o nome de "leigos"!

Por outro lado, o caráter secular do leigo é algo tão forte na consciência eclesial e tão insistentemente reafirmado que, de "próprio e peculiar dos leigos" (LG 31), deslisa com facilidade para "específico". O perigo nem sempre é percebido: se a índole secular for "específica" dos leigos e leigas, estamos diante de uma "definição" e, por lógica, os clérigos e os religiosos estariam privados de "secularidade". Não é que não seriam do mundo em sentido místico-espíritual-ético - o que se diz de todo autêntico discípulo e discípula - mas em sentido ontológico-físico-social - o que os tornaria seres tão exóticos como o "ET" de Varginha, o lobisomem e a mula-sem-cabeça. Pero que los hay, hay! O Vaticano II tinha clara consciência dessa dificuldade tanto que optou não por uma definição (impossível) ontológica do leigo, mas por uma "descrição tipológica" e, ao fazê-la, diz que os ministros ordenados podem, "às vezes (aliquando), ocupar-se em assuntos seculares, exercendo até profissão secular" (LG 31). Por isso, prefiro a expressão do prof. Lazzati: a índole secular - compartilhada por toda a Igreja e por todos os seus membros - é "plena" nos leigos e nas leigas. ${ }^{91}$ Sendo plena, tem que ser plena, segundo o antigo adágio: "agere sequitur esse" (o agir segue o ser). O leigo e a leiga devem, em todas as circunstâncias - desde a mais intraeclesial até à mais intramundana - exprimir o Evangelho segundo a "índole secular" que lhes é própria e peculiar.

Excluíndo aquelas concepções inadequadas ou errôneas, é possível tirar desse tesouro acumulado em séculos "coisas velhas e boas", como ensina o sábio do Evangelho. Não para fazer arqueologia, mas para alimentar de vida e esperança a precariedade do presente com os olhos fixos no Reino que há de vir. Precisamos aprender a ser dóceis. É a primeira atitude do crente diante da Verdade que vem ao seu encontro: uma atitude não de posse ou de arrogância, mas a disposição de aprender, de dar e receber. A segunda é aprender com os pequenos, os simples, os mansos e humildades de coração. Vivem sua condição cristã e leiga sem conhecer teologia e muito menos sem refletir teologicamente sobre a condição dos leigos e leigas na Igreja e no mundo. Em certo sentido, para eles, a realidade é mais verdadeira, porque concreta e única; não fazem tantas distinções, mas desejam para "já" "o outro mundo",

${ }^{91}$ LAZZATI, G. Laicità e impegno cristiano nelle realtà temporali. Roma: AVE, 1985. 
"a outra vida", o "outro mundo possível". A reflexão só tem a ganhar com "os grandes olhos dos simples." ${ }^{2}$

\section{Referências bibliográficas}

ALMEIDA, A. J. Leigos em quê? Uma abordagem histórica. São Paulo: Paulinas, 2006.

CANOBBIO, G. Laici o Cristiani? Elementi storico-sistematici per una descrizione del cristiano laico. Brescia: Morcelliana, 1992.

CANOBBIO, G. "La riflessione teologica sui laici dal Concilio a oggi". In: NAVARRO, L.; PUIG, F. (ed.). Il fedele laico. Realtà e prospettive. Milano: Giuffrè, 2012.

CATTANEO, E. I ministeri nella Chiesa antica. Testi patristici dei primi tre secoli. Milano: Paoline, 1997.

CONGAR, Y. Jalons pour une théologie du laïcat. Paris: Cerf, 1953. (Os leigos na Igreja. Escalões para uma teologia do laicato. São Paulo: Herder, 1966).

CONGAR, Y. Problèmes de l'autorité. Paris: Cerf, 1962.

CONGAR, Y. "Laïc et Laïcat". In: Dictionnaire de spiritualité. Ascétique et mystique. Doctrine et histoire. Paris: Beauchesne, Tomo IX, coll. 79-108.

CONGAR, Y. “Leigo”. In: FRIES H. (ed.). Dicionário de teologia. Conceitos fundamentais da teologia atual, III. São Paulo: Loyola, pp. 127-149.

CONGAR, Y. Ministères et communion ecclésiale. Paris: Cerf, 1971. (Ministeri e comunione ecclesiale. Bologna, EDB, 1973).

DELORME, J. (ed.). Elministerio y los ministerios según el Nuevo Testamento. Madrid: Cristiandad, 1975.

DUPUIS, J. "Lay People in Church and World. The Contribution of Recent Literature to a Synodal Theme". Gregorianum 68 (1-2/1987), pp. 347-390.

${ }^{92}$ ZIVIANI, G. Luigi Sartori a colloquio con Giampietro Ziviani. Una mentalità ecumênica, Op. cit., p. 155. 
FAIVRE, A. Les laïcs aux origines de l'Église. Paris: Éditions du Centurion, 1984. (I laici nelle origini della Chiesa. Milano: Cinisello Balsamo, 1986).

LAGARDE, G. La naissance de l'esprit laïque au déclin du Moyen Age. Paris - Louvain: Nauwelaerts, 1956ss.

LANNE, E. "Le laïcat dans l'Église ancienne". Verbum Caro. Revue théologique et ecclésiastique 71-72 (1964), pp. 105-126.

LAZZATI, G. Laicità e impegno cristiano nelle realtà temporali. Roma: AVE, 1985.

LAZZATI, G. Il laico. Roma: AVE, 1986.

LEGRAND, H. "Ministerios de la Iglesia local". In: LAURET, B. REFOULÉ, F. Iniciación a la práctica de la teologia. Dogmática 2. Madrid: Cristiandad, 1985, pp. 87-137.

POTTERIE, I. "L'origine et le sens primitif du mot laïc". Nouvelle Revue Théologique 80 (1959), pp. 840-853.

THILS, G. Théologie des réalités terrestres. I. Préludes. Paris: Desclée de Brower, 1946.

ZIVIANI, G. Una Chiesa di popolo. Bologna: EDB, 2011.

Antonio José de Almeida Doutor em Teologia pela Pontificia Università Gregoriana (Roma) Professor do Programa de Pós-Graduação da PUCPR Curitiba / PR - Brasil E-mail: ajacatedral@uol.com.br

Recebido em: 26/01/15

Aprovado em: 14/04/15 